\begin{tabular}{ll} 
短 報 \\
\hline
\end{tabular}

\section{人工種苗メバル，クロソイおよび カサゴにおける鼻孔隔皮欠損の出現状況}

\section{松岡 正信*}

(2007 年 4 月 27 日受付, 2007 年 10 月 30 日受理) 独水産総合研究センター瀬戸内海区水産研究所

Occurrence of deformity of the inter-nostril epidermis in artificially raised black rockfish Sebastes inermis, jacopever Sebastes schlegeli and Japanese stingfish Sebastiscus marmoratus juveniles

\section{MASANOBU MATSUOKA*}

National Research Institute of Fisheries and Environment of Inland Sea, Fisheries Research Agency, Hatsukaichi, Hiroshima 739-0452, Japan

キーワード：カサゴ, クロソイ, 胎生魚, 鼻孔隔皮欠 損, メバル

人工魚にみられる鼻孔隔皮欠損は, 前鼻孔と後鼻孔の 間の隔皮が欠如または短縮し, 両鼻孔が連続する形態異 常である。これまでにマダイ Pagrus major, 1) イサキ Parapristipoma trilineatum, ${ }^{2,3)}$ トラフグ Takifugu rubripes , 4) スズキ Lateolabrax japonicus , 5) クロダイ Acanthopagrus schlegeli, 6) カンパチ Seriora dumerili, キジハ タ Epinephelus akaara, ヒラメ Paralichthys olivaceus, ${ }^{3)}$ アユPlecoglossus altivelis ${ }^{7}$ およびサワラ Scomberomorus niphonius $^{8)}$ で確認されて抢り, 天然魚では極めて稀で ある。9-11) そこで，マダイでは放流種苗を天然魚と識別 するための標識として鼻孔隔皮欠損が用いられてい る。 ${ }^{12)}$

しかし、これまでに観察された 10 種類の人工種苗魚 は全て卵生魚であり, 発育特性や繁殖特性の異なる更に 多くの重要栽培漁業対象魚種について鼻孔隔皮欠損の出 現状況を検討する必要がある。7) 今回は, 胎生魚で比較 的大きな仔魚を産仔するメバル Sebastes inermis, クロ ソイ Sebastes schlegeli 打よびカサゴ Sebastiscus marmoratus について鼻孔隔皮欠損の出現状況を調査し, そ の放流種苗の標識としての可能性について検討したので 報告する。

本研究に用いたメバル標本は, 2002 年に広島県の栽 培漁業機関で生産された 115 個体（全長 $15.0 \sim 34.0$ $\mathrm{mm}$, 平均 $20.5 \mathrm{~mm}$ ）である。クロソイの標本は, 1993 年に水産庁瀬戸内海区水産研究所 (現: 独水産総合研究 センター瀬戸内海区水産研究所）で生産され, 保存され
ていた 99 個体（全長 $24.0 \sim 54.0 \mathrm{~mm}$, 平均 $37.1 \mathrm{~mm}$ ) である。カサゴの標本は，2004 年に宮崎県（全長 22.4
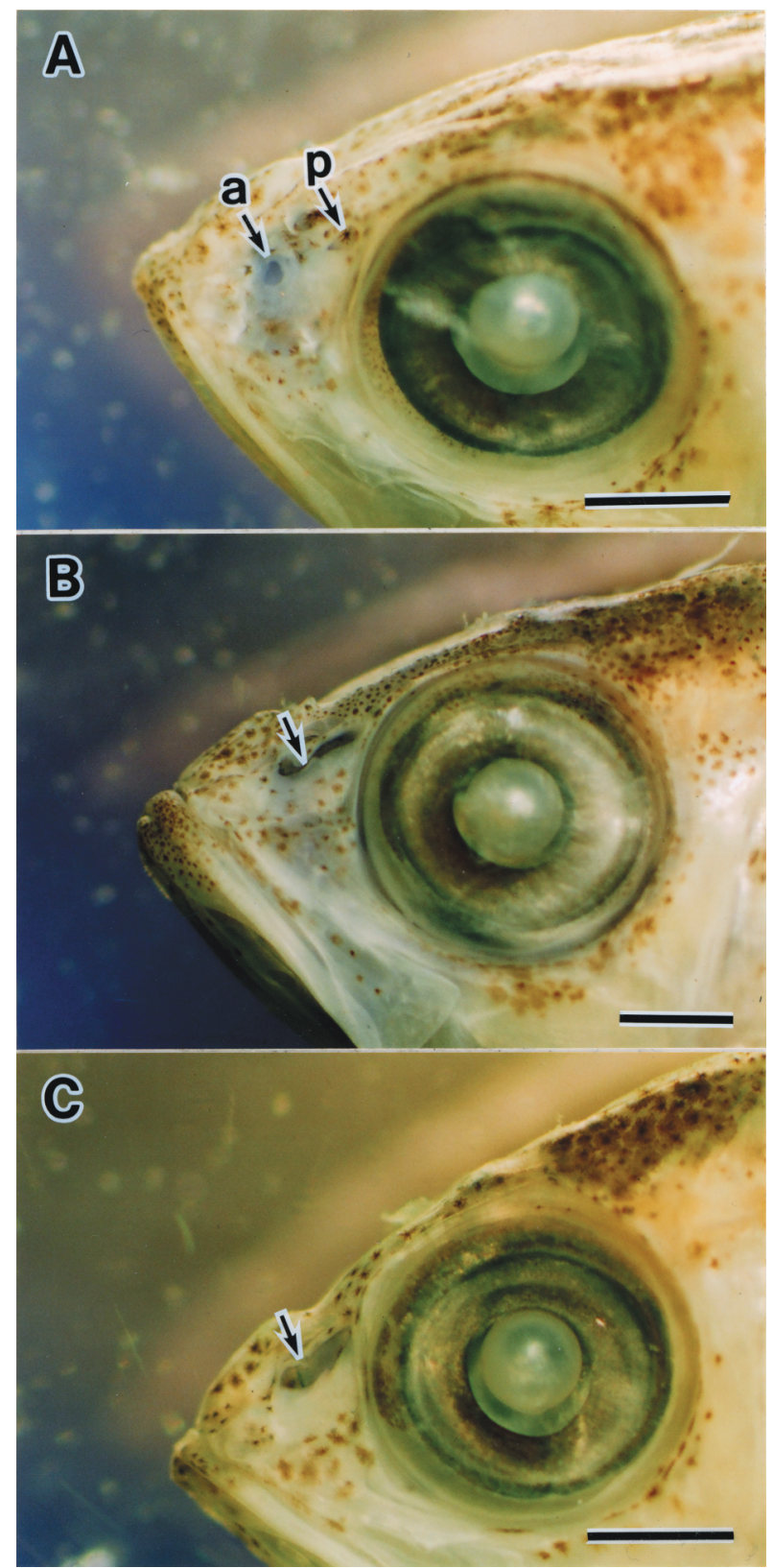

Fig. 1 The nostrils of artificially raised black rockfish. (A): stage IV = a normal nostril structure (arrows). a, anterior nostril; p, posterior nostril. (B): stage III of the deformed nostril structure with long nostril epidermises but not fused (arrow). (C): stage II of the deformed nostril structure with short nostril epidermis (arrow). Bars indicate $1 \mathrm{~mm}$.

* Tel : 81-829-55-0666. Fax : 81-829-54-1216. Email : yamame@fra.affrc.go.jp 
$\sim 34.0 \mathrm{~mm}$, 平均 $28.0 \mathrm{~mm}, 110$ 個体), 長崎県 $\mathrm{A}$ (全長 $46.8 \sim 61.4 \mathrm{~mm}$, 平均 $54.7 \mathrm{~mm}, 107$ 個体), 長崎県 B （全長 $18.3 \sim 28.7 \mathrm{~mm}$, 平均 $23.9 \mathrm{~mm}, 152$ 個体）およ び山口県の栽培漁業機関（全長 $16.2 \sim 30.1 \mathrm{~mm}$, 平均 $21.7 \mathrm{~mm}, 156$ 個体) でそれぞれ生産されたものである。 これらの標本の鼻孔隔皮欠損の状況を確認するため, 実体顕微鏡下で観察した。鼻孔周辺の色素が薄い標本 は, シアニン $5 \mathrm{R}$ の飽和水溶液の希釈液に $2 \sim 3$ 分浸漬 した後, 淡水中で観察した。

鼻孔隔皮欠損の程度の指標として，体側の片側だけの 欠損と両側の欠損を区別した。鼻孔隔皮の発達段階は安 樂ら 13)の区分を若干改変し, 鼻孔隔皮が全く発達して いないものをステージI, 鼻孔隔皮の伸長の程度の低い ものをステージII, 上下の鼻孔隔皮が接する付近まで伸 長しているが, 瘉合していないものをステージIII, 完全 に癒合したものをステージN とした。両側の鼻孔につい ては，例えば，片側がステージIで他方がステージIIの 場合はII + III と表した。左右は考慮しなかった（Table 1)。3 魚種においてステージI は全く認められなかった ので，損の程度が強いII + II の出現率に注目した。

メバルに㧍ける片側の鼻孔隔皮欠損は $23.5 \%$, 両側 の久損は $56.5 \%$, 合計 $80.0 \%$ であった。その他に前鼻 孔の欠損したものが $0.9 \%$ みられた。このうち，II +II の個体は 54.8\%であった（Table 1)。Fig. 1 はステー
ジN（正常）（Fig. 1A），ステージIII（Fig. 1B）および ステージII (Fig. 1C) を示している。

クロソイに打ける片側の鼻孔隔皮欠損は $24.2 \%$, 両 側の欠損は $9.1 \%$, 合計 $33.3 \%$ であった。このうち, II + II の個体は 4.0\%であった（Table 1)。

宮崎県のカサゴに打ける片側の鼻孔隔皮欠損は 6.4 $\%$, 両側の欠損は $3.6 \%$, 合計 $10.0 \%$ であった。

長崎県 $\mathrm{A}$ のカサゴに打ける片側の鼻孔隔皮欠損は $31.8 \%$, 両側の欠損は $6.5 \%$, 合計 $38.3 \%$ であった。

長崎県 Bのカサゴにおける片側の鼻孔隔皮欠損は $28.9 \%$, 両側の欠損は $40.1 \%$, 合計 $69.0 \%$ であった。 このうち， II + II の個体は 25.7\% であった (Table 1)。

山口県のカサゴに打ける片側の鼻孔隔皮欠損は 42.9 $\%$, 両側の欠損は $27.6 \%$, 合計 $70.5 \%$ であった。この うち，II + IIの個体は 10.9\%であった（Table 1)。 今回の観察結果から, 分離浮性卵や沈性卵より器官形 成が更に進んだ段階で産仔されるメバル, クロソイおよ びカサゴのような胎生魚でも鼻孔隔皮欠損が出現するこ とが明らかとなった。従って, ごく初期の摂餌時期の違 いが鼻孔隔皮欠損の発現に与える影響は少ないものと考 えられる。

メバルに拈ける鼻孔隔皮欠損の出現率は $80.0 \%$ と 3 種類中最も高く，そのうち，両側の欠損は $56.5 \%$, ま た，明瞭なII +IIの欠損が $54.8 \%$ を占めた。このこと

Table 1 Results of the observed nostrils of black rockfish, jacopever and Japanese stingfish juveniles raised artificially (Japanese stingfishes of Miyazaki and Nagasaki A are not shown)

\begin{tabular}{|c|c|c|c|c|c|c|c|c|}
\hline \multirow{2}{*}{$\begin{array}{r}\text { Species } \\
\text { Black rockfish }\end{array}$} & \multirow{2}{*}{$\begin{array}{l}\text { Sampling site } \\
\text { Hiroshima }\end{array}$} & \multirow{2}{*}{$\begin{array}{c}\begin{array}{c}\text { No. of } \\
\text { specimens }\end{array} \\
115\end{array}$} & \multirow{2}{*}{$\begin{array}{c}\begin{array}{c}\text { Total length } \\
(\mathrm{mm})\end{array} \\
15.0-34.0\end{array}$} & \multirow{2}{*}{$\begin{array}{c}\begin{array}{c}\text { Normal } \\
\text { specimens }\end{array}(\%) \\
19.1\end{array}$} & \multicolumn{2}{|c|}{$\begin{array}{l}\text { Deformed } \\
\text { specimens (\%) }\end{array}$} & \multicolumn{2}{|c|}{$\begin{array}{c}\text { Component of deformed } \\
\text { nostril stages }(\%)\end{array}$} \\
\hline & & & & & one side & 23.5 & $\mathbb{I I}^{*}+\mathrm{II}$ & 54.8 \\
\hline & & & & & both sides & 56.5 & II + III $^{*}$ & 1.7 \\
\hline & & & & & others & 0.9 & II $+\mathbb{N}^{*}$ & 22.6 \\
\hline & & & & & total & 80.9 & III + III & 0 \\
\hline & & & & & & & III $+\mathbb{N}$ & 0.9 \\
\hline \multirow[t]{5}{*}{ Jacopever } & Hiroshima & 99 & $24.0-54.0$ & 66.7 & one side & 24.2 & II + II & 4.0 \\
\hline & & & & & both sides & 9.1 & II + III & 0 \\
\hline & & & & & total & 33.3 & II $+\mathrm{N}$ & 17.2 \\
\hline & & & & & & & III + III & 5.1 \\
\hline & & & & & & & $\mathrm{III}+\mathrm{N}$ & 7.1 \\
\hline \multirow[t]{5}{*}{ Japanese stingfish } & Nagasaki B & 152 & $18.3-28.7$ & 30.9 & one side & 28.9 & II + II & 25.7 \\
\hline & & & & & both sides & 40.1 & II + III & 10.5 \\
\hline & & & & & total & 69.0 & II $+\mathrm{N}$ & 23.0 \\
\hline & & & & & & & III + III & 4.6 \\
\hline & & & & & & & III $+\mathbb{N}$ & 5.3 \\
\hline \multirow[t]{5}{*}{ Japanese stingfish } & Yamaguchi & 156 & $16.2-30.1$ & 29.5 & one side & 42.9 & II + II & 10.9 \\
\hline & & & & & both sides & 27.6 & II + III & 8.3 \\
\hline & & & & & total & 70.5 & II $+\mathbb{N}$ & 31.4 \\
\hline & & & & & & & III + III & 8.3 \\
\hline & & & & & & & III $+\mathbb{N}$ & 11.5 \\
\hline
\end{tabular}

$\mathrm{II}^{*}, \mathrm{II}^{*}$ and $\mathrm{N}^{*}$ indicate the developmental stages of inter-nostril epidermis. 
から，本種において鼻孔隔皮欠損が有効な放流種苗の標 識となる可能性が示唆された。

クロソイの鼻孔隔皮欠損出現率は $33.3 \%$ とメバルに 比べてかなり低く，そのうち，II+Iの欠損が $4.0 \%$ と 少なかったことから考えると，放流種苗の標識としての 利用可能性はメバルに比べて低いと考えられる。しか し，メバル抢よびクロソイについては各 1 例しか検討 していないことから，更に観察例を増やす必要がある。

4 機関に打いて生産されたカサゴでは, 鼻孔隔皮欠損 出現率は， $10.0 \%, 38.3 \%, 69.0 \%$ 抢よび $70.5 \%$ と大き く異なっていた。しかし，2機関においてメバルに次ぐ 高い欠損率が認められたことから，放流種苗の標識とし て用いられる可能性は否定できない。

傍島ら ${ }^{9)}$ にると，マダイでは種苗生産機関によって 鼻孔隔皮欠損の出現率にかなり差があると報告されてい る。松岡 6,7$)$ はクロダイとアユで同様の結果を報告して いる。飼育機関による鼻孔隔皮欠損出現率の差異は，飼 育方法の僅かな違いによると考えられるが，7）現在のと ころ明らかではない。

今回は本来鼻孔が完成するサイズ以上の標本を観察し たので，鼻孔隔皮の形成過程に関する知見は示されてい ない。この点に関しては, シリーズ標本の観察によって 明らかにする必要がある。

\section{謝辞}

本研究に用いた標本を提供していただいた，広島県水 産試験場，財宮崎県栽培漁業協会，社山口県栽培漁業公 社第二外海栽培漁業センター, 佐世保市水産センター, 長崎県栽培漁業公社の職員各位並びに東海大学鈴木伸洋 博士に深謝申し上げる。

\section{文献}

1）後藤正則. 養殖マダイにみられた鼻孔の形態異常につい て. 栽培技研 $1986 ; 15: 87-88$.

2）熊本県栽培漁業協会. イサキ人工種苗に見られた鼻孔隔 皮欠損について。栽培漁業事例集 (平成 10 年度版)，水 産庁資源生産推進部栽培養殖課，東京. 1999; 53-54.

3）松岡正信. カンパチ, イサキ, キジハタおよびヒラメに 抢ける鼻孔隔皮欠損の出現状況. 水産増殖 2004; 52: 307-311.

4) 長崎県. 種苗放流実態調査. 平成 $7 \sim 11$ 年度放流技術開 発事業報告 (トラフグ), 山口県・福岡県・長崎県・三重 県・愛知県・静岡県・秋田県. $2000 ; 5$.

5）茨城県水産試験場. スズキ人工種苗に認められる鼻孔隔 皮の形態異常. 平成 7 年度 9 年度放流技術開発事業報 告書 (スズキ), 茨城県水産試験場・大分県海洋水産研究 センター浅海研究所. 1998; 13-15.

6）松岡正信. クロダイの鼻孔隔皮欠損症について. 水産増 殖 2000; 48: 675-676.

7）松岡正信. 人工採苗アユの鼻孔隔皮欠損. 水産増殖 2004; 52: 425-426.

8）松岡正信. 人工種苗サワラの鼻孔隔皮欠損. 水産増殖 2008; 56: 141-143.

9）傍島直樹，宗清正廣，船田秀之助，鼻孔隔皮の欠損によ るマダイ放流種苗と天然魚の識別の可能性. 京都府海洋 センター研報 1986; 10: 35-40.

10）愛知県水産試験場. 鼻孔隔皮欠損. 平成11年度放流技術 開発事業報告書（中回遊種トラフグ）, 愛知県水産試験 場. $2000 ; 17$.

11）松岡正信.コモンフグ天然魚にみられた鼻孔隔皮異常に ついて. 水産増殖 2002; 50: 233-234.

12) Imai $\mathrm{T}$. Sea farming of red sea bream Pagrus major (Temminck et Schlegel) in waters off Kanagawa Prefecture, Japan with special reference to stock enhancement effect. Kanagawa Prefec. Res. Bull. 2005; 10: 65-71.

13）安樂和彦, 外田知子, 川村軍蔵, Mana RR. 人工種苗マ ダイの鼻孔隔皮形成過程. 日水誌 1999; 65: 501-502. 